\title{
CODE MIXING IN ISLAMIC LECTURES BY USTADZ EVIE EFFENDI
}

\author{
Asep Triana ${ }^{1}$, Siddik Sembada Eka Saputra ${ }^{2}$ \\ ${ }^{1}$ IKIP Siliwangi, Bandung \\ ${ }^{2}$ IKIP Siliwangi, Bandung \\ ${ }^{1}$ aseptriana00@ gmail.com, ${ }^{2}$ siddik_dafa@yahoo.co.id
}

\begin{abstract}
This study is aimed to find the kinds of code mixing and to know which kinds of code mixing are dominantly used in Islamic lectures by Ustadz Evie Effendi. Descriptive qualitative method is used in this study. The data were collected through watching, transferring, asking, playing, selecting and transcribing the data from the lectures. The collected data were then analyzed through identifying the data, selecting the data related to the code mixing, listing and classifying the data based on the kinds of code mixing and finally drawing conclusion. It was found that there are two kinds of code mixing used by Ustadz Evie Effendi, namely conversational and situational code mixing. Between two kinds of code mixing, conversational code mixing is dominantly used both by Ustadz Evie Effendi in which he sometimes change the pronunciation from English into Indonesian in the conversation.
\end{abstract}

Keywords: code mixing, kinds of code mixing, Islamic lectures

\section{INTRODUCTION}

Indonesia is a big country with various religion. It is written in Indonesian ideology namely Pancasila especially on the first principle, "Believe in almighty God", it means that to believe in God is the best choice as Indonesian society. Religion has a big role in people daily life, it is the most important part of human right, so is Islam. Islam is the most adhered religion in Indonesia. it has a big role in this social life and human being. The believer of Islam called "muslim". Many Muslim in this country who want to believe more in Allah. However they are still learning to be a good muslim. The indicator of a good muslim based on Hadits is the more useful people is the more Allah loves him. This is why they need to charge their Iman in order to be more faithful and obedient. Allah Ta'ala says"And whoever does righteous deeds, whether male or female, while being a believer - those will enter Paradise and will not be wronged, [even as much as] the speck on a date seed." [Qur'an, 4: 124 ]. This Qur'an chapter is motivated the writer to do this research and in order to increase the Iman of now Muslim.

There are many ways to build up the Iman, such as by reciting Al Qur'an, praying on time and listen to Islamic lectures. In the former time, islamic lectures is not as well-known as now. Even though there are a few of islamic lecturer which is called a million ummah ustadz like Ustadz Zainuddin MZ. In this modern era, there are so many islamic lecturers, even in Indonesia specifically in Bandung. Bandung has a lot of talented da'i(lecturer). One of them is Ustadz Evie Effendi. Many muslim citizen in Bandung love and like to listen to his lecture, it is proved by many people come to ustadz Evie lecture and many of them said that the lecturer's language style and humble are the reason why they love it. His lectures is so clear and easy to understand for every Muslim even for non Muslim. His lectures make many people want to Hijrah (be a better muslim). It happened because Ustadz Evie Effendy used to 
be a sinful person. He wants to be a better person and invite people to be an obedient ummah. In his lectures, he brings a lot of code mixing and code switching. The researcher only analyze the English Indonesian and Sundanese code mixing. Because in his utterance of lectures there is also Arabic Indonesian code mixing such as "makanya Iqro, baca!". The informent has so many code mixing and code switching. However this research only conduct the English, Indonesian, and Sundanese code mixing.

\section{Code switching}

When a person communicates with other persons, he or she sends a code to the receiver. The speaker and receiver must understand the code. Code will be something he or she may want to call a language which is accessed by the speaker. Bilingual speakers have access to two codes that can be shifted as the converse, either by code switching or code mixing. According to Wardhaugh (2006), people are usually required to "select a particular code whenever they choose to speak, and they may also decide to switch from one code to another even within sometimes very short utterances and thereby create a new code in a process known as code switching" (p.100). Code switching is potentially the most creative aspect of bilingual speech. The most general description about code switching is that it involves the alternate use of two languages or linguistic varieties within the same utterance or during the same conversation (Hoffmann, 1991, p. 109-110). It can be concluded that code switching is the speakers switch their language to totally other language in order to make the addressees understand what their saying to others. Wardhaugh (2002) divides code switching into situational and metaphorical. Situational code switching occurs when the languages used change according to the situations in which the conversant find themselves; they speak one language in one situation and another in a different one. Furthermore, metaphorical code switching occurs when a change of a topic requires a change in the language used. The interesting point here is that some topics may be discussed in either code, but the choice of code adds a distinct flavor to what is said about topic. For examples, the use of the former for an activity always discussed in a particular language, the use of the latter to evoke special feeling, the speaker changes the code as he or she redefine the situation formal to informal, official to personal, serious to humorous, and politeness to solidarity.

\section{Code Mixing}

Wardhaugh (1986, p. 103) states that "code mixing occurs when conversants use both languages together to extend that they change from one language to other in the course of a single utterance". In addition, Redlinger \& Park (1980), cited in (Hoffmann: 1991) define language mixing as the combining of elements from two languages in a single utterance. It occurs when a speaker uses a certain language in his communication; however, he inserts some pieces of another language. Therefore, it can be concluded that code mixing is a speaker inserts or mixes two languages in a single utterances and it usually occurs in informal situation.

According to Wardhaugh (1986) there are two kinds of code mixing. They are situational and conversational. Situational code-mixing occurs when conversant use both languages together to the extent that they change from one language to the other in the course of a single utterance. What we observe is that one variety is used in a certain set situations and another in an entirely different set. However, the changeover from one to the other may be instantaneous or spontaneous related with the topic being discussed. Situational code mixing occurs when the language used change according to the situation in which the conversant find them; they speak one language in one situation and another language in different one. But, 
conversational code-mixing involves the deliberate mixing of two languages without an associated topic change. (Platt, H K. \& John, 1975)Plaff (1979, cited in (Wardhaugh: 1986) provides the following example of conversational code-mixing among Spanish- English bilinguals:

No van a bring it up in the meeting

„They are not going to bring it up in the meetinge

Estaba training para pelear

„He was training to fight ${ }^{e}$

Etc.

In short, such conversational code-mixing is often used by bilinguals, primarily as a solidarity marker. A speaker who mixes codes in this way in conversation with a friend of acquaintance will almost certainly shift entirely to English when addressing a monolingual Englishspeaking person or entirely Spanish origin. The people to make the situational or condition lively usually use conversational code mixing.

This research is conducted to analyze and explore more about code mixing used by the speaker. many his listener love him because of the way his lectures, language style and code mixing that he used. That is why this research is conducted, because the researcher in interested to analyze and explore more about code mixing that informent used in every his lectures, so because of that this research entitled "Code Mixing in Islamic Lectures by Ustadz Evie Effendi”.

\section{METHOD}

This study used descriptive qualitative based on the nature of situation that was described the phenomena of code mixing in Ustadz Evie Effendi lectures. The objects of this study was the lecturer of Islamic Lectures, Ustadz Evie Effendi. The Instruments were Interview and watching the lectures and recording it, transferring and playing the data several times, selecting the data related to the aim of the study and finally rewriting or transcribing the data. The collected data analyzed through identifying the data, selected the data relate to the code mixing, list and classified it based on the kinds of code mixing and finally drawing conclusion.

\section{RESULTS AND DISCUSSION}

\section{Results}

This study was aimed to find the kinds of code mixing used by Ustadz Evie Effendi in his lectures. This study reveals that there are two kinds of code mixing, namely conversational code mixing and situational code mixing. The following is the detailed (the bold words/phrases are the code mixing): 


\section{Tables}

\section{Conversational Code Mixing}

A. Theme : Jomblo ti baheula

No. Conversational Code Mixing Meaning

\begin{tabular}{lll}
\hline 1. & Iyeu teh character building. & This is a character building. \\
\hline 2. & Jangan berburuk sangka sama Allah, ini motivasi & Don't be negative thinking to \\
& buat out of the zone dari zona kesendirian. & Allah, because this is a \\
& motivation to get out of the \\
& lonely zone.
\end{tabular}

3. Kita kan mau berkembang biak diimbangi dengan We want to grow up while berkembang baik, you want marry me? Take me growing much better. out Indonesia.

4. Orang bisa menikah dengan siapapun tapi sorry to People can marry to everyone say orang ga bisa menentukan cintanya untuk but sorry to say, people can not siapapun.

5. Aku tambah Allah cukup, miracle, amazing, I am enough with Allah. unlimited luar biasa.

6. Capek me ngejar bayang bayang tinggalkan aja Dear my ex. I was so sorry for dan biar bayang bayang itu mengejar kita, Dear my past.

mantan maafkan aku yang dulu, jangan tanya aku dimasa lalu.

7. Yuk kenali Allah lebih dekat dan cari tahu lebih Let's know Allah more and jauh so sweetnya Allah ke kita.

8. Eh eh eh kalem life is by process, process for Easy, life is by procees, don't success don't protest. protest until success.

\section{B. Theme : OTW To Death}

\begin{tabular}{lll}
\hline No. & \multicolumn{1}{c}{ Conversational Code Mixing } & \multicolumn{1}{c}{ Meaning } \\
\hline 1. & $\begin{array}{l}\text { Lalu kalau kita berbuat baik di caption diupload } \\
\text { banyak viewer liker and lover lalu irung } \\
\text { ngabeukahan hati hati. }\end{array}$ & $\begin{array}{l}\text { If there are so many likers, } \\
\text { lovers or viewer in our } \\
\text { instagram, it will make us } \\
\text { arrogant. }\end{array}$ \\
\hline 2. & $\begin{array}{l}\text { Ngomongkeun kematian hati hati lah buku iyeu } \\
\text { adventure mantak kade ah. }\end{array}$ & $\begin{array}{l}\text { When we talk about death, be } \\
\text { careful because this book is } \\
\text { very scarying. }\end{array}$ \\
\hline 3. & $\begin{array}{l}\text { Dibuku ini itu ternyata ijroil itu } \text { everyday } \\
\text { everytime } \text { everywhere } \text { selalu dateng ngecek kuota } \\
\text { setiap manusia. }\end{array}$ & $\begin{array}{l}\text { It is written in this book that } \\
\text { Ijroil always comes every } \\
\text { single time. }\end{array}$ \\
\hline 4. & $\begin{array}{l}\text { Da alam kubur mah lain kuburan maka perlu } \\
\text { berbekal for } \text { otw to death yang namannya ilmu } \\
\text { iman islam. }\end{array}$ & $\begin{array}{l}\text { We need to prepare for facing } \\
\text { the death as good as possible. }\end{array}$ \\
\hline 5. & $\begin{array}{l}\text { Da kabeh ge hayang ka surga geus katingali } \\
\text { bengeutna } \text { horny hararayang ka surga. }\end{array}$ & $\begin{array}{l}\text { I do know that you all here } \\
\text { really want to be in heaven of } \\
\text { Allah ta'ala }\end{array}$ \\
&
\end{tabular}


C. Theme : Rek Kitu Wae

\begin{tabular}{lll}
\hline No. & \multicolumn{1}{c}{ Conversational Code Mixing } & \multicolumn{1}{c}{ Meaning } \\
\hline 1. & $\begin{array}{l}\text { Sok ustadz evie mah gampang dan sorry ya sorry } \\
\text { to say aku mah ga pasang tarif. }\end{array}$ & $\begin{array}{l}\text { I am soory, I don't need any } \\
\text { fee to state my lectures }\end{array}$ \\
\hline 2. & Aya teu empati peduli charity bukan hanya cerita. & $\begin{array}{l}\text { Is there any charity without } \\
\text { just talk only? }\end{array}$ \\
\hline 3. & $\begin{array}{l}\text { Click selalu dengan iman refresh dengan doa open } \\
\text { dengan harapan dan tampilkan } \text { screen perjalanan } \\
\text { hidup kita selama berjalan dikehidupan. }\end{array}$ & $\begin{array}{l}\text { We need to improve more our } \\
\text { eemaan and we need to try } \\
\text { harder to stay on the track } \\
\text { (Istiqomah) }\end{array}$ \\
\hline
\end{tabular}

D. Theme : Sebaik baiknya Manusia

No. Conversational Code Mixing Meaning

1. Secara automatically keluar dari out of the zone jahilliyyah.

When people hijrah, they will automatically get out from the bad habit.

2. Maka packaging harapan, hajat dan cita-cita. We need to hope more to Allah.

3. Amal rahasia miracle giving sodaqoh.

4. Akhirnya pas si dokter ini low section.

Giving is a miracle. When the doctor is low section(telling a story)

5. Terakumulasi everything semuanya. Things will be accumulated.

6. Hirup mah pilihan life is a choice. Life is a choice.

7. Rindu tiada terperih why. Missing is hurt.

8. Dakwah itu bukan cerita tapi charity, empati dan Dakwah is not only a story but peduli. also a charity, care, and emphaty.

9. Tidak harus kontan cash and carry. There is no cash and carry.

10. Punten saya punya quote sok tulis sok. Excuse me, i have quote, please write it.

11. Sangat di hargai kalo kita respect. If we respect others we will be respected.

12. Maka empat choicenya pilih salah satu. There are four choices, just choose one.

13. Aya we nu new comer mah, can apaleun urang ustadz.

There is a new comer who don't know that I am an Ustadz.

14. Lamun ges tunduh sleep keun moal allright If you are so sleepy, just sleep. sarekeun moal bener. Because it will not be allright.

15. Dari sister side silakan. $\quad$ From sister side, please ask.

16. Karena berbuat kebaikan banyak penghalangnya, There are so many trouble karena hidup is never flat when we want to do good deeds.

17. Aa kenapa bisa seperti ini what's wrong? Geuleuh Honey, what's wrong? It is a boga ustadz teh kamalinaan big no to have an Ustadz like him. (telling a story)

18. Aa tenang jangan berburuk sangka Allah Don't be so negative thinking 
tergantung prasangka kita, aku juga lonely. to Allah babe. (telling a story)

E. Theme : Allah segala galanya.

No. Conversational Code Mixing Meaning

1. Nyeri awak lamun teu nyieun update status teh. It is so exhausted when we don't upade status.

2. Dados: dakwah on the street. It is an abbreviation which telling his activity in dakwah.

3. Life is a process, Allah bisa nyieun langsung bisa Life is a process, Allah can mere langsung. give and create in a sec.

F. Theme : Firaun dan Iblis pun beriman II

No. Conversational Code Mixing Meaning

1. Juara sekali tema kali ini stay on the track memang seperti itu lah manusia seharusnya.

People is created to stay on the track (istiqomah).

2. Bersikap lah proportional, stay on the track karena untuk itu manusia di ciptakan. People is created to stay on the track (istiqomah), be proportional.

3. Alhamdulilah istiqomah stay on the track. Give thanks to Allah because we can stay on the track (istiqomah)

4. Kalo hanya beriman punten sorry dory worry Sorry, Pharaoh was also a firaun juga beriman. believer.

5. Ingin naik berajat ingin naik stage naik tahapan. We need to upgrade our level so our stage will accelerate.

6. Religion is poison agamanya di racun. When religion is poisoned.

7. Nato: no action talk only ngomong saja karena tidak ihklas.

It is an abbreviation to show how unimportant if we just talk only.

8. Nabi menghargai stay on the track orang yang beramal kecil.

9. Istiqomah kalo dalam bahasa arabnya memberdirikan, bahasa sundanya jegjereg kalo bahasa hukumnya mah consistant kalo bahasa umumnya continue.

10. Karena manusia di ciptakan untuk itu lalu keluar Because people is created to be out of the track lawan stay on the track.

Our prophet Muhammad very appreciate the little thing. Istiqomah meaning is a continuity. istiqomah.

11. Maka mobil aja ada handbook nya, motor ada Our handbook is Al Qur'an. handbook nya, hp ada handbook nya lalu manusia handbook nya apa? Al-qur'an.

12. Istiqomah stay on the track jangan out of the track jangan keluar dari track istiqomah kieu we hirup mah.

13. Hayang rame weh biar to be continue. I want to keep continue in istiqomah.

14. Doa yang merubah karena hidup is never flat Prayer will change the destiny. hidup ga pernah lurus. 
15. Ustadz bagaimana tips and tricknya iya kalo dalam syariah mah jaga wudhu minta tuntunan dan minta bimbingan.

16. Sok pertanyakan pada diri stay on the track naon nu ges di istiqomahkeun.
Ustadz, can i know how tips and trick to keep our wudhu, and please guide us.

Please ask yourself, are you still istiqomah or not.

G. Theme : Ganteng cantik ga akad, seseuh tah bengeut

No. Conversational Code Mixing Meaning

1. Yang penting itu inner beauty. It is beautiful. The most important is an inner beauty.

2. Buka surat an-nur ayat 2 sebagai review saja. Please open surah An nuur as our review.

3. Ceuk nu ges boga mah teu cukup nya, right. It is not enough when you have it, right?

4. Ada pernyataan ada pertanyaan bawa enjoy aja Easy, just ask to me. sok.

5. $\quad$ Next ada, itu yang merah.

The red one please.

6. Tapi hubungan jalan terus akhirnya, punten married by accident.

Sorry, there is also marriageby an accident.

H. Theme : My hijrah my adventure

No. Conversational Code Mixing Meaning

1. Jadi sebuah trademark baru bangga dengan hijrah. It is a new trademark by hijrah.

2. Maka tag lah setelah hijrah istiqomah. We need to istiqomah.

3. Sok ratu tentukan pilihanmu sekarang, take me Please choose your choice out Indonesia. $\quad$ Ratu. (point the audience)

4. Dunia semakin jauh dan menjauh akhirat semakin We will die soon, so just be mendekat dan mendekat, injury time nya bukan well-prepared. no urut atau no antri tapi no cabut atau no dudut.

5. Perasaan gaeanak berarti homeless, teu nanaon When you feel not bad, means ngan nanaonan. you are homeless.

6. Maka di kampanyekeun hey the real man go to It is campaigned, real men go masjid. to masjid.

7. Slow but sure kalem we rek kamana. Just take it easy.

8. Hati hati dengan pekerjaan tangan finishing on Becareful with our hands job. hand.

9. Urang ulin ka Australia tiap imah tulisan na home There are so many home sweet home aya hammer, alphard. which written "home sweet home" in Australia.

10. Hanya doa yang merubah takdir never give up Prayer will change the destiny, berbisiklah kepada bumi langitpun mendengar. never give up.

\section{Situational Code Mixing}

A. Theme : Jomblo ti baheula

No. Conversational Code Mixing Meaning 


\begin{tabular}{lll}
\hline 1. & Jomblo itu terkadang membuat strong oge sih. & $\begin{array}{l}\text { Sometimes, being jomblo } \\
\text { makes us strong. }\end{array}$ \\
\hline 2. & Muzammil kenapa sold out karena berprestasi. & $\begin{array}{l}\text { Why Muzammil is sold out? } \\
\text { Because he has an } \\
\text { achievement. }\end{array}$ \\
& & $\begin{array}{l}\text { Let's finish this by reciting } \\
\text { Qur'an. }\end{array}$ \\
\hline 3. & Sok tadz baca heula ayatna kita finishing. & Being single is not a big deal. \\
\hline 4. & Jomblo ti baheula artinya jadi no problem. &
\end{tabular}

B. Theme : OTW To Death

No. Conversational Code Mixing

1. Jadi offside hidupnya sering dapat kartu merah dan kartu kuning karena sering melampaui batas dari batas ketentuan yang Allah sudah gariskan.

2. Ningali watsap geus hudang tidur teh asa menang After waking up, we don't wahyu ti jibril padahal teu apal sabaraha kali know how many Ijroil calls us. incoming call ti jibril.

C. Theme : Rek Kitu Wae

No. Conversational Code Mixing

Meaning

1. Yang saya khawatirkan dari social media saya facebook mah geus kamana mah lapur ai saya mah resep malah bengeut viral dimamana.

2. Ini teh cerita yang tadi ini teh inspiring. I am just worry of the harmful of social media like facebook.

3. Turungan ku kaos endorse nya nu geus gombrang. Just cover it by using a loosing endorse shirt.

4. Cek urang teh stress aya nu ciga urang. I say, there is also a stress man like me.

D. Theme : Sebaik baiknya Manusia

No. Conversational Code Mixing Meaning

1. Soflware yang Allah ciptakan hati. Our heart is a software that Allah created.

2. Banyak mem-pending kebaikan sehingga pagojud. It is a very bigproblem when you pending a good deeds.

3. Allah gapernah tidur, allah gapernah salah, Allah is never wrong, because miracle. it is a miracle.

4. Apalagi selfie teu nanaon ngan nanaonan. Selfie is not recommended.

5. Nabi mah engga, humble weh. Our prophet is not arrogant, he is vey humble.

6. Tapi gaboleh judging dulu gaboleh punishment We can not do judging as we dulu. want.

7. Geroan weh teh please? Kenapa mau pulang Just call her, why do you want bareng. to go home with me.

8. Dia akhirnya ikut on the street kamana-mana. And finally he follow us to dakwah. 
9. Keur hangout ge kadarieu-kadarieu arulin wae asakeun sate.

10. Dia kebagian manfaatnya multilevel marketing dia jadi up linenya.

11. Jadi harus menciptakan soflware.

12. Kebaikan mah kebalikannya selfie dulu.

E. Theme : Allah segala galanya.

No. Conversational Code Mixing

1. Teu kuat hayang nyieun quote.

2. Ada masa expirednya.

3. Komitmennya jieun quote lebih baik kehilang sesuatu karena allah daripada kehilangan allah karena sesuatu.

4. Tuh nu ngarasa pinter mah firaun offside.
When you hangout just come here to taste sate.

$\mathrm{He}$ is an upline in his multilevel marketing. We need to create software. A good is just done by selfie.

F. Theme : Firaun dan Iblis pun beriman II

No. Conversational Code Mixing Meaning

1. Alhamdulilah abdi mah istiqomah tara ka goda ku Alhamdulillah i never be nu puasa. Awas yeuh stay on the track dimana. flirted.

2. Gararaya ieu the keur naon, kalo hanya sholat Sorry, we need to have a sorry sholatnya harus berkualitas.

3. Keep istiqomah cicing. Just keep istiqomah.

4. Di body guard ran nage ku malaikat. Our bodyguard is an angel

5. Karena hidup mah offroad berat. Life is very hard.

G. Theme : Ganteng cantik ga akad, seseuh tah bengeut

No. Conversational Code Mixing Meaning

1. Di poto na alus di editan beautiful. cowo In a photo is handsome pertamina, berminyak.

2. Menang kekeset welcome. because it has been editted. Get the doormat.

H. Theme : My hijrah my adventure

No. Conversational Code Mixing Meaning

1. Hijrah adalah pertaubatan bukan life style. Hijrah is a regretful not a life style.

2. Ini habit baru nyeri awak lamun teu nyieun status This new habit is we will be teh. exhausted if we do not update status.

3. Dek kamana ieu teh follower pengajian rame teh There are so many my rek dibawa kamana. follower who want to follow me. 
Based on the tables above, in those lectures themes there are eight themes. It was found there are 69 conversational code mixing in 8 themes and 36 situational code mixing in 8 themes. It can be concluded that the dominant code mixing used by Ustadz Evie is a conversational code mixing.

\section{Discussion}

Based on the data findings and analysis of code mixing that used in Islamic lectures by Ustadz Evie, it was found that there were 69 conversational code mixing used in his lectures and 36 situational code mixing.

According to Wardhaugh (1986) there are two kinds of code mixing. They are situational and conversational. Situational code-mixing occurs when conversant use both languages together to the extent that they change from one language to the other in the course of a single utterance. conversational code-mixing is often used by bilinguals, primarily as a solidarity marker. A speaker who mixes codes in this way in conversation with a friend of acquaintance will almost certainly shift entirely to English.

Ustadz Evie Effendi applied situational code mixing when he mixed between Indonesian Sundanese and English together based on the situation in the lectures and he also mixed both languages without an associated topic change. The conversational code mixing applied because Ustadz Evie Effendi is very humble, humorist, smart and friendly. After doing tge interview to the speaker, the writer can conclude that code mixing is the way how Ustadz Evie convey his lectures.

The dominant kinds of code mixing were found in the lectures of Ustadz Evie Effendi was conversational code mixing in which he sometimes change the pronunciation from English to Indonesian in the lecture. The biggest reason why he mostly used conversational code mixing is because he is very up to date to this era and his talent to mix languages and that is the way he convey his lecture as well.

\section{CONCLUSION}

Code mixing was used by Ustadz Evie Effendi in many his lectures show. He used three languages, English, Indonesian and Sundanese together in his utterances. He was able to mix his languages in the lecturesa and conversation spontaneously. It can be so friendly to the audiences and easier to be understood. The reason why Ustadz Evi mix his languages is because he is talented as he said in question and answer session in his meet and greet Gapleh book at Landmark building on Saturday, 03rd of March 2018. Many his audiences stated that he chose to mix the language because he wants to introduce Sundanese and International language to the audiences. There are two kinds of code mixing, namely situational and conversational code mixing. It is known that the speaker used situational code mixing to make the lectures more interesting. Besides, he also used conversational code mixing to make every single his lectures more alive. Code mixing in the lectures used in relaxed and informal condition. The speaker used English and Indonesian code mixing in his lectures. Moreover, his utterances were also understandable to the viewers.

Following the conclusion, hopefully, this study can be as a basis for next researchers. In this research, it is focused on the analysis type of code mixing used in Ustadz Evie utterances in his lectures This study was also recommended to the lecturers, the students and the future researchers. For the lecturers, the result of this study can be as additional information especially for sociolinguistics subject. The material can be used as consideration in preparing, selecting and constructing for sociolinguistics class. English lecturesrs are recommended to get some inspiration in sociolinguistics subject which related to code mixing material. For the students, it is hoped that by knowing the results of this study, they will know code mixing 
between Indonesian, English and Sundanese were used in Ustadz Evie Effendi lectures and it can be as a reference to study linguistics. For the future researchers, it is hoped that they can find code mixing in other ustadz such as Ustadz Absul Somad, Ustadz Handy Bonny, etc. Besides, the future researchers are also hoped that they can find the motivation of the speakers why they use code mixing and they can find other code mixing not only Indonesian, English and Sundanese code mixing but also English and other languages such as Germany, Spanish, Malay, etc.

\section{ACKNOWLEDGMENTS}

Finally, the writers are indebted to their parents. Special thanks to Miss Rissa San Rizqiya, S.Pd., M.Pd., and our lovely lectures in English Department of IKIP Siliwangi Bandung for guiding and supporting us to make this journal completely finish. 


\section{REFERENCES}

Hamidah, Fitria, N. (2015). Code Mixing Found in Islamic Lectures by Bukan Empat Mata Channel on Trans 7 Television Channel. Kediri.

Hoffmann, C. (1991). An Introduction to Bilingualism. London and New York: Longman Inc.

Nursjam, (2004). Indonesian-English Code Mixing in Tourism Contesxt. Hasanudin University.

Platt, H K. \& John, T P. (1975). The Social Significance of Speech: an Introduction to an workbook in sociolinguistics. Amsterdam/Newyork.

Redlinger, W. E., \& Park, T. (1980). Language mixing in young bilinguals. Journal of Child Language 7, 337-352.

Wardhaugh, R. (1986). An Introduction to Sociolinguistics (4th ed.). New York: Blackwell. Wardhaugh, R. (2006). An Introduction to Sociolinguistics (5th ed.). New York: Blackwell. https://quran.com/4/124 